\title{
SRETNI GRAD - PRIMJENJIVOST PETRIĆEVA KONCEPTA EUTOPIJE U SUVREMENOM KONTEKSTU
}

\author{
Ana Jerković \\ Filozofski fakultet, \\ Sveučilište u Splitu, Hrvatska \\ anajerkovic80@gmail.com
}

Frane Petrić sa svojim je djelom Sretni grad nesumnjivo dao doprinos nizu povijesnih pokušaja osmišljavanja savršenog mjesta za život i blagostanje građana. Ovaj je renesansni filozof na tragu Aristotela ocrtao konture položaja, društvenog ustrojstva, modela obrazovanja $i$ drugih elemenata polisa koji bi, po svemu sudeći, trebali riješiti manjkavosti gradova odnosno država njegova vremena. Koliko se njegova slika idealnog grada uklapa u današnji, suvremeni kontekst? Koje ideje bi mogle i trebale zaživjeti, a koje su obilježene duhom i ograničenjima njegova vremena? Slijedom toga, koje su univerzalne vrijednosti koje $i$ danas ne gube na cijeni i potrebitosti jednako kao i stotinama godina ranije?

Ključne riječi: Frane Petrić, Sretni grad, utopija, idealna država, suvremenost, univerzalnost

\section{Uvod}

Brojna povijesna i filozofska djela intrigiraju svojom aktualnošću i vizionarstvom, a među njima se posebno izdvajaju ona koja se odnose na društvene odnose, sustav vrijednosti pojedinca i društva, ljudska prava te stremljenja $\mathrm{k}$ idealnom društvenom uređenju. Potonje se fenomenološki naročito ističe jer zahtijeva široku naobrazbu u području društvenih i humanističkih znanosti, praćenje društvenih trendova, poznavanje osnovnih ustrojstvenih jedinica političkih sustava, uvid u znanstvene, etičke i druge zakone, razumijevanje ljudske prirode. 
Slijedom raznolikosti vremena i prostora na kojima je nastajao i djelovao, utopijski model mišljenja prošao je mnoge faze - od idealizma preko pragmatizma do distopije i antiutopije. Uz pomoć Sretnog grada Frane Petrića mogu se razložiti tri ključne komponente utopijskih djela - uvjetovanost, aktualnost i univerzalnost. Drugim riječima, obilježenost vremenom u kojem je tekst stvaran, njegova suvremenost te univerzalna primjenjivost. Primjerom Sretnog grada metodološki je moguće prikazati spomenutu trihotomiju s posebnim osvrtom na njegovu drugu komponentu - aktualnost, jer nam je najbliža i najzanimljivija u ovome trenutku.

\section{Pojam utopije}

Čovjek oduvijek teži za istim ciljevima - srećom i blagostanjem, kako kroz povijest tako i danas. Filozofi i mislitelji prošlosti pokušavali su stvoriti model sadašnjosti ili budućnosti u kojemu ljudi ne bi morali razmišljati o pukoj materijalnoj egzistenciji, već bi se orijentirali k razvoju vrlina, umjetničkom stvaranju, znanstvenom istraživanju i filozofsko-duhovnim spoznajama. Slijedom toga, postoji cijela jedna niša literature, kako filozofske, društveno-političke i teološke tako i fikcijske, koja se bavi pojmom i opisom idealnog društva odnosno savršenog mjesta za život. Takvi tipovi vizija odnosno idejnih konstrukta poznati

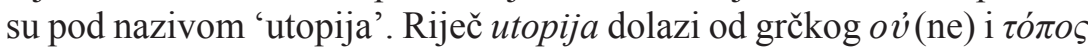
(mjesto, kraj, okolica), što znači 'ne-mjesto' ili 'mjesto koje ne postoji' (Majnarić i Gorski, 1960, 407, 559). Prvi je ovu riječ upotrijebio engleski filozof i humanist Thomas More u svom djelu Utopija (1516) nazivajući tako zamišljenu otočnu državu u Atlantiku.

Za Lewisa Mumforda utopija je nešto nestvarno i nemoguće, suprotstavljeno »zbiljskom svijetu«, a što svijet čini podnošljivijim (Mumford, 2008, 9). Riječ je, dakako, o dubokom i plemenitom promišljanju boljeg i pravednijeg svijeta, a ne o nepraktičnom fantaziranju. Kako uvjeti odnosno okolnosti nikada nisu idealni niti jednaki, tako je glavni problem idealne države njena održivost. Ipak, kako postoje normativističko-ontologijski i empirijski pristupi stvarnosti, tako je nužno da postoji ideal ili savršena ideja kojoj bi država, grad ili zajednica trebali težiti. Takve ideje i ideali daju čovjeku usmjerenje i težnju da svojim djelovanjem barem dijelom doprinese ostvarenju arhetipa raja na zem1ji, čega su dokaz permanentne pojave utopijskih djela kroz povijest. 
Moramo se, međutim, osvrnuti i na skretanja s putanje idealizma političkih sustava koji su obilježili noviju povijest, poput komunizma/ socijalizma - koji je u svojoj suštini i definiciji bilježio plemenite ciljeve, jednakost i bratstvo svih ljudi, zajedničko vlasništvo, besklasno društvo. No budući da teorija i praksa često ne korespondiraju, svaka se dosadašnja ideologija dala zloupotrijebiti. Uz to, kako je stalna samo mijena, potvrdilo se i da civilizacija, poput živog bića, podliježe zakonu ciklusa. Zato je utopija za sada doista mjesto koje ne postoji jer se na početku svake postavlja nužno pitanje njene opstojnosti odnosno dugoročne održivosti.

Slijedom logike i analogije mikro i makrokozmosa, idealnu državu mogli bismo oformiti ukoliko bi nam uspjelo stvoriti idealnog čovjeka. Budući da to nije realno, moguće je stvoriti samo idejnu sliku savršenog ljudskog bića. Jer, bi li idealan čovjek bio smrtan? Ako je odgovor negativan, onda bi implicirao da bi savršena država trajala vječno. Ako bi trajala vječno, koja bi onda bila njezina svrha i kako bi se stalno i iznova uspijevala modernizirati?

\section{Utopija kroz povijest}

Najpoznatija utopija nedvojbeno je Platonova Država (5. st. pr. Kr.). Viđenje optimalnog ali realnog društveno-političkog konstrukta iznio je njegov učenik Aristotel u nekoliko svojih djela (Politika, Ustav atenski, Nikomahova etika). Platona su slijedili i interpretirali brojni kasniji mislitelji, a možemo istaknuti Grad vrlina Al-Farabija (9. st.), osnivača arapske skolastike, koji je svoju Savršenu (ili Vrlu) državu gotovo potpuno preslikao od svog uzora (Bučan, 2009). Temelje kršćanske filozofije u 5. stoljeću iznosi Aurelije Augustin u djelu $O$ državi Božjoj. Renesansu je obilježio Thomas More svojom Utopijom (1516), dok je kroz satirični roman Gargantua i Pantagruel (1532) svoje humanističke ideje prezentirao François Rabelais. Johann Valentin Andreae u svom Christianopolisu (1619) opisao je kršćansku utopiju kao zajednicu učenjaka koji žive u demokraciji. Tommaso Campanella pak u svome Gradu sunca (1623) prikazuje teokratsko i egalitarno društvo. Francis Bacon u Novoj Atlantidi (1627) ističe znanstveni sveučilišni centar kao okosnicu zemlje visokog morala i pobožnosti, a već i samim naslovom djela vraća se na Platona, koji je prvi spominjao mitsku Atlantidu. Još bismo mogli istaknuti djelo engleskog političkog filozo- 
fa Jamesa Harringtona The Commonwealth of Oceana (1656), pamflet engleskog reformatora Gerrarda Winstanleya The Law of Freedom in a Platform (1652) te brojna druga. Kraj 18. i 19. stoljeće obilježila je prije svega Francuska revolucija, na zamahu koje su svoja političko-filozofska promišljanja idealnog društva konstruirali filozof progresa Henri Saint-Simon te kasnije njegov učenik Auguste Comte i Robert Owen. Marksisti su, kako ističe britanski sociolog Krishan Kumar, utopiju otpravili u ropotarnicu povijesti kao varku doba koja su mogla samo sanjati o valjanom društvu.

»Sada su znanost i tehnologija devetnaestog stoljeća te snaga običnih ljudi dobavljali ono o čemu se u prijašnjim vremenima moglo samo maštati. (...) U svjetlu toga, književna je utopija privremeno zamrla. Pisani oblik koji je, potaknut Utopijom Thomasa Morea (iz 1516. godine), bujao diljem Europe, dosežući svojevrstan vrhunac u osamnaestom stoljeću, praktički je nestao u prvoj polovici devetnaestog stoljeća. Utopijska socijalna teorija te eksperimentalna utopijska zajednica postale su, nasuprot književne utopije, ono što se tražilo.« (Kumar, 2000, 75)

Ipak, književnu utopiju obnavljaju Osvrt unatrag Edwarda Bellamya (1888) i Vijesti iz Nedođije (1892) Williama Morrisa u kojem autor zagovara vrstu liberalnog socijalizma i dekonstrukciju klasičnog pojma obitelji. Drugačiji prikaz nalazimo u romanima A Crystal Age (1906) W. H. Hudsona i Men like Gods (1923) engleskog pisca H. G. Wellsa, gdje ljudi žive u anarhiji te smatraju obrazovanje i znanstvena istraživanja svojom vladom. Životinjska farma Georgea Orwella (1945) alegorijski ali zorno prikazuje kako se vlast korumpira i prvotna plemenita ideja biva zloupotrebljenom. Orwell se vraćao utopiji (odnosno distopiji) u čuvenom djelu 1984., kao i Aldous Huxley, koji se u dva svoja djela - Vrli novi svijet (1932) i Otok (1962), upustio u potragu za idealnim društvom.

Kraj 20. i početak 21. stoljeća u utopističkom smislu obilježili su romani, novele, novi mediji, film, znanstvena fantastika, od čega su mnogi svoje idealne uvjete smjestili ne na otocima i preko mora i oceana, već na drugim planetima i/ili u kozmičkom prostoru. U članku Hrvoja Jurića (2005) nalazimo izjave suvremenih teoretičara o tome da su utopija i utopistički duh danas diskreditirani, čitamo o »smrti utopije« i današnjim utopijskim razmišljanjima koja su neučinkovita i namijenjena dokonim intelektualcima. Kumar (2001) tvrdi suprotno i navodi kako je pojava feminističkih i ekoloških utopija dokaz da utopija nipošto nije iscrpila svoju moć bilo kao alat kritičke analize ili konstruktivne vizije 
budućih mogućnosti. Utopija se slijedom toga transformirala u razne oblike aktivizma i borbe za ljudska prava - od feminističkog pokreta, emancipacije LGBT populacije, prava životinja, preko rasne, vjerske i nacionalne tolerancije, do globalnih pokreta otpora kapitalizmu. Hoće li utopijski duh preživjeti, oživjeti u novom obliku ili posve nestati, pokazat će vrijeme. No oduvijek je utopijska misao bila budućnosna, kako zaključuje Hrvoje Jurić (2005), te bi se mogli složiti s njegovom konstatacijom: misliti utopijski znači - misliti.

\section{Petrićev Sretni grad kao utopija}

Utopije se, logično, javljaju u vremenima snažnih socijalnih, političkih i gospodarskih previranja. Slijedom nezadovoljstva postojećim okolnostima, filozofi i teolozi osjećaju potrebu za stvaranjem koncepta koji bi dao nadu i osvijestio nužnost stvaranja boljih uvjeta života za sve ili barem za veći dio građana. Mumford $(2008,10)$ ističe kako je npr. Platonova Država nastala slijedom reperkusija Peloponeskog rata, a Moreova Utopija iz sukoba poretka srednjeg vijeka s novim vrijednosnim sustavom renesanse. Frane Petrić je kao dječak svjedočio ratnim zbivanjima Mlečana protiv Osmanskog carstva, a i sama događanja u Europi u tom razdoblju bila su koliko izazovna toliko i inspirativna.

Kumar ističe kako je »utopijski pisac primoran predstaviti potpuno razvijenu i razrađenu sliku sretnog svijeta za koji se očekuje da će nastupiti primjenom određenih načela« (Kumar, 2001, 76). Tako je $L a$ Città Felice (Sretni grad) »jedno od najiznimnijih tekstova u širokoj panorami 15. i 16. stoljeća, u njegovoj estetici i poetici grada, filozofskih traktata o najboljem društvenom uređenju kao i arhitektonsko-urbanističkih projekcija«, smatra Ljerka Schiffler (1997, 43). Petrićevo djelo nastalo je 1551. godine, a objavljeno je 1553. u Veneciji. Iako se općenito svrstava u utopijsku književnost, sam autor navodi da nije pretenciozno i samo je »skroman prilog « savjetodavnog karaktera za upravljanje gradom, a upućen vlastelinima Vigeriju i Girolamu dalla Rovere. Mislav Kukoč pak navodi da ono nema ni utopijski ni eshatološki karakter u odnosu na prethodne utopijske koncepcije te ga karakterizira kao »socijalno-filozofijsko djelo« (Kukoč, 1995, 173).

Kronološki, Sretni grad smješten je između Moreove Utopije i Grada sunca Tommasa Campanelle, a prema mišljenju brojnih autora Petrić se oslanjao ponajviše na Aristotelov realizam te se vodio nje- 
govim viđenjem i sadržajnom strukturom optimalnog pragmatičnog društvenog uređenja. Već su Lino Veljak i Vladimir Premec ustanovili ovu poveznicu, a Kukoč je izložio niz podudarnosti između Petrićeva i Aristotelova modela promišljanja (Kukoč, 2009, 645). Štoviše, u spisu Sretni grad Petrić doslovno slijedi analize iz VII. i VIII. knjige Politike, tvrdi Kukoč $(2009,652)$, uz dodatak da velik dio djela čini svojevrsno prepričavanje Aristotelovih teza. Francesco Bottin $(1997,58)$ ističe da je, usprkos platonističkim namjerama, Sretni grad otvoreno i eksplicitno priznanje aristotelovske filozofije. Sam Petrić u uvodu svog rada spominje sažimanje Aristotelovih državnih uređenja i ustava, koje bi trebao imati grad bi bio uspješan odnosno sretan (Petrić, 1998, 7). Dakle, Petrićevi filozofski uzori su evidentni.

Vraćajući se na etimologiju, More, osim naziva 'utopija', sugerira i drugi termin - 'eutopia', što implicira 'sretno mjesto' ( $\varepsilon v$ - grč. dobro, pravo, valjano, sretno, zdravo, lijepo; Majnarić i Gorski, 1960, 230). ${ }^{1}$ Dakle, možemo zaključiti da je Frane Petrić svojim nazivom 'Sretni grad' odabrao upravo ovaj smisao, ukazujući na realno mjesto, nešto što je moguće dosegnuti, a ne na imaginarnu predodžbu idealnog grada-države. I Kukoč $(2009,652)$ izdvaja Aristotelov eudaimonizam kao polaznu etimološku i vrijednosnu točku Petrićeva koncepta. Persida Lazarević Di Giacomo $(2010,386)$ izvodi zaključak iz etimologije talijanskog izvornika La Città Felice da se radi o pristupu upravo građanima i gradu kao jednom entitetu (lat. civitas) ali i plodonosnom, produktivnom i blaženom mjestu (lat. felix i fecundus) te dodaje da Petriću nije svrha razmotriti aspekte idealnog već uspješnog i funkcionalnog grada.

\section{Položaj grada}

Frane Petrić svoj je grad očito smjestio na Mediteranu. Razradio je impresivno detaljne upute o položaju mjesta s obzirom na njegov obrambeni potencijal, trgovačku povezanost preko mora i kopna, a dotaknuo se i ekološko-zdravstvenih elemenata uzevši u obzir klimu, omjer hladnoće i topline, prozračnost, tlo, blizinu vode, zbog čega ga Schiffler naziva »urbanističkim idealom « (Schiffler, 1997).

\footnotetext{
${ }^{1}$ Posljednjih godina se u javnom prostoru pojam eutopija koristi najčešće kao termin koji spaja EU (Europsku Uniju) i utopiju, a kojim se ukazuje na Europsku Uniju kao ideju zajedništva, jednakosti i solidarnosti te se kroz ovaj pojam propituje njen karakter, prakse i politike.
} 
Petrić se poziva na pozitivne primjere tadašnje Verone i Atene, mediteranske gradove s najboljom klimom i položajem za nesmetan rast i razvoj. Mediteran kao kolijevka civilizacije oduvijek je bio pogodno područje za ekspanziju duha i kultura, a kao sjecište i poveznica triju kontinenata izrodio je niz moćnih kako stvarnih tako i mitskih gradova, polisa i država. Stoga ne čudi da je putnik Petrić odabrao konkretno, a ne imaginarno mjesto za postizanje sreće.

Između ostalog, Petrić se dotaknuo i opasnosti od zagađenosti zraka i to u vremenu prije razvoja industrije, prometa i drugih uzroka onečišćenja. Savjetuje zdrav i nepokvaren zrak daleko od močvara, blata i ustajalih voda, a izložen vjetrovima i zračnim strujama. Vizija sretnog grada zanimljiva je i u zdravstveno-medicinskom smislu, s obzirom da je Petrić studirao medicinu, kako navodi Biserka Belicza $(1999,215)$. Svijest o (zdravstvenoj) ekologiji i atraktivnosti gradova i zemalja zbog klime i blagodati položaja ne mogu biti aktualnije.

Što se obrambenog potencijala polisa tiče, Petrić je živio u vremenu obilježenom ratovima - grad je stoga trebalo izgraditi van dometa ili teško dostupnog neprijatelju. Osvrnuvši se na aktualni trenutak, pet stoljeća kasnije, velike svjetske sile deklarativno nastoje očuvati mir te se za promociju mira svake godine dodjeljuje i Nobelova nagrada, dok se paralelno osmišljavaju najrazličitiji tipovi oružja za masovno uništenje - nuklearno, biološko, kemijsko i slično. Slijedom toga, Petrićeva ideja o strateškom položaju grada danas ne bi imala mnogo efekta jer, bez obzira gdje on bio smješten, ako se zarati modernim oružjima, bit će u dometu neprijatelja (bilo zračnim, morskim ili kopnenim putem) - barem kada je riječ o Europi, SAD-u i većim napučenim područjima. Danas svjedočimo cijelom nizu ratnih zbivanja u svijetu, ponajviše na Bliskom Istoku i u Africi, a svjedočili smo i nedavnom ratu u jugoistočnoj Europi. Koliko su strateške pozicije i obrane bile efikasne? Na psihološkoj pak razini danas se ratuje diljem svijeta i to preko medija, računala, raznim vrstama manipulacija, često vrlo suptilnim, od čega ne postoji način obrane osim materijalnom neovisnošću, njegovanjem vrlina i kritičkog mišljenja. Postavlja se pitanje kako bi danas uopće izgledala optimalna obrana? I sam diskurs novog, »nevidljivog «, virtualnog rata otvara niz mogućnosti za daljnje rasprave.

Prije globalizacije, interneta i nadirućeg globalnog vijeka, sa znatno užom percepcijom karte svijeta, Petrić je morao misliti lokalno, u okviru poznatog, te su strateški položaj, obrambeni potencijal i kompaktnost strukture grada bili jedan od imperativa njegovog opstanka. 


\section{Staleži}

U kontekstu staleža u idealnim strukturama, Platonova Država ih ima tri - filozofe, vojnike i proizvođače; Aristotel pak društvo stratificira na one koji su dijelovi države i one koji se moraju nalaziti u državi, odnosno na upravljački i stalež robova; a na Istoku hinduizam na sličan način kategorizira četiri kaste - brahmane (svećenstvo), kšatrije (vojnike i vladare), vajšije (trgovce i obrtnike) i šudre (radnike i seljake). Petrić se odlučio za šest staleža, od kojih su tri povlaštena, a tri podjarmljena. Sve djelatnosti potrebne za opstanak tako su bile pokrivene - u nižim slojevima seljaci, obrtnici i trgovci, a u višima vojnici, upravljači i svećenici. Nejasno je pak gdje je smjestio umjetnike, znanstvenike i filozofe - potonje, vjerojatno, u upravljače. Iz autorovog teksta ne može se zaključiti ni postoji li i svojevrstan tip meritokracije, odnosno je li moguće iz jednog staleža prijeći/napredovati u drugi. Kako je primijetio Bruno Ćurko u svojoj analizi Petrićeva viđenja vrline i sreće: »Petrićev grad neće biti sretan za sve njegove stanovnike, nego samo za izabrane iz triju 'viših' staleža« (Ćurko, 2010, 400). Teško da možemo zamisliti da bi ljudi bili sretni ako cijeli život samo služe te su izuzeti iz građanstva i pripadajućih beneficija. U tom se smislu Petrić ponovno naslanjao na Aristotelovo ontologijsko razlikovanje slobodnog čovjeka i roba (Kukoč, 1995, 175). Dakle, Sretni grad bio bi nesretan za onaj dio stanovništva koji nema privilegije baviti se vrlinom. Ova postavka bi u suvremenom društvu bila potpuno neprihvatljiva.

Karl-Heinz Gerschmann je, na tragu analogije mikro i makrokozmosa, usporedio Petrićev grad s ljudskim tijelom - koje treba hranu, piće, zaštitu, druženje, obrazovanje i vladavinu uma (Gerschmann, 1979). S tim u vezi, mogli bismo povezati tri niža staleža kao onaj nesvjesni dio čovjeka, povezan uz vegetativne funkcije, a tri viša sa svjesnim, koji jedini i može pojmiti sreću. U tom smislu bi staleška podjela imala uporište u mikrokozmičkom poretku, a i sam Petrić uspoređuje državu s tijelom koje služi duši. Platon je također državu uspoređivao s čovjekom nazivajući je "povećanom slikom čovjeka«, no imajući u vidu trihotomiju ljudske duše. I suvremeno bi se društvo dalo podijeliti na više skupina, kako po kategorijama društvenih slojeva tako i prema svjesnosti.

Shodno tome, svaka utopija, radilo se o imaginarnom nedostižnom obliku zajednice ili realnoj primjeni na postojeći sustav, obilježena je vremenom i trendovima u kojima autor stvara. Tako je bilo nemogu- 
će za Franu Petrića, unatoč obrazovanju i širini vidika, postaviti svoj optimalni polis u okvir zrele demokracije ili evoluirane anarhije. Analogno, današnjem mislitelju ne bi bilo korisno niti bi bilo prihvaćeno da svoje napredno društvo podijeli u staleže. Opća klima, običaji, navike, ustaljeno ponašanje, kolektivna svijest, mediji i popularno zvani mainstream skloni su i podložni demokraciji koja daje sva prava građaninu-pojedincu. Kako smo već napomenuli, staleži danas postoje, ali percepcija jednakosti toliko je snažna da bi demokraciju bilo iluzorno uopće pokušati slomiti nekim novim oblikom formalne stratifikacije. Slično razmišlja i Lazarević Di Giacomo $(2010,390)$ navodeći da Petrićeva rasprava nije u stanju poštivati logiku koncepcije demokratske zajednice.

\section{Odgoj i obrazovanje}

Dva su načina odgoja građana - nagradama za dobro djelovanje i kaznama za loše. Svjestan toga bio je i Petrić te je naveo kako duševnu pokvarenost liječe odnosno preveniraju ljubav i druženje, dok od izvršenja zlodjela odvraća strah od kazne (Petrić, 1998, 19). Kazne se definiraju kvalitetnim i pravednim zakonima, a za provođenje zakona potrebne su pravosudne institucije odnosno funkcionalna pravna država. Jednako je i danas.

Obrazovanje pak uvijek mora sadržavati dvije komponente - kvantitativnu i kvalitativnu, odnosno informativnu i formativnu. Kako je čovjek dvojno biće - duhovno i materijalno, mora izučavati sve što se tiče obje stvarnosti. Petrić veliku pozornost poklanja »spekulativnim vrlinama«, odnosno duhovnosti i kreativnosti, što treba poticati i probuditi već u najranijoj dobi. U tom smislu ističe glazbu i likovnost, dakle razvijanje smisla za estetiku i stvaranje.

Kako je čovjek dvojstvo tijela i duše, pa i duša dvojstvo razumskog i nerazumskog, a tijelo je stvoreno radi duše, nerazumsko pomiješano s tijelom služi razumskom i djeluje prvo, što razumsko ne čini jer je najviše ljudsko savršenstvo, mišljenja je Petrić $(1998,31)$. Isto vrijedi i danas, u ponešto izmijenjenoj terminologiji (dušu u znanosti mijenja više ili manje pogođen naziv 'psiha').

Petrić ističe da je ljudima »u dušama prirodno utisnuta vjera« kao i da »čovjeku nije ništa manje svojstvena vjera od nagona i prirodne žudnje za životom u zajednici« (Petrić, 1998, 26). Dakle, duhovna na- 
obrazba je također potrebna, kako u renesansi tako i danas, no ne u dogmatskom već u etičkom smislu. Čovjek mora postići intelektualnu zrelost i psihičku stabilnost, izgraditi oba polariteta kako bi bio uravnoteženo i cjelovito biće. Ipak, suvremenoj znanosti trebat će vremena dok teološko-duhovne spoznaje ne integrira sa znanstvenima u jednu cjelovitu i zaokruženu Znanost. Tek takvo znanje bit će sveobuhvatno i nuditi integrativnu naobrazbu mladom čovjeku željnom odgovora na sva ontološka pitanja. Iz kvalitetnog obrazovanja uma i odgoja karaktera mladi čovjek može postići sreću pronalazeći i radeći posao koji voli, a za koji ima predispozicije i talent. Isto bi trebalo biti poticano i od strane sustava. S takvim preduvjetom pravednosti i društvenomaterijalnom neovisnošću, mladi suvremeni čovjek svoju »božansku dokolicu« mogao bi posvetiti višim disciplinama, duhovnosti, estetici, istraživanju, umjetničkom stvaranju i kontemplaciji.

\section{Primjenjivost koncepta Sretnog grada u suvremenom kontekstu}

Sretni grad autor je napisao sa samo 22 godine, što znači da je već kao mladić razmišljao o najboljem mogućem društvenom ustrojstvu. Iako djelo nije elaborat, nego je kratko i nestrukturirano, pisano poput pisma, može se naslutiti u kojemu će se smjeru dalje razvijati ovaj hrvatski filozof. Bilo bi pak zanimljivo vidjeti kako bi na kraju svog životnog vijeka Petrić opisao savršeni polis.

Kakogod, stvoriti ili oformiti sretan grad ili grad s idealnim uvjetima života u suvremenom kontekstu svakako ne bi bilo ni jednostavno ni jednoznačno. Prije svega jer u današnjem svijetu svaka država, unija zemalja i kontinenti nose svoje kvalitete, izazove i specifičnosti pa isti model ne bi bilo moguće primijeniti na različite kulture, narode, političke sustave i religije. Uz to, kako smo već i spomenuli, dugoročna održivost modela bila bi upitna. Ipak, mediteranski tip grada svakako bi morao zadovoljavati dobre klimatske uvjete, optimalan broj stanovnika, sadržavati sva potrebna zanimanja u proizvodnom procesu, imati kvalitetan obrazovni, upravljački i pravni sustav te trgovačku i prometnu povezanost s drugim gradovima i državama. Pojedinac bi trebao imati slobodu da se obrazuje, uzdiže i razvija do mjere do koje želi, može, i do koje je pravedno. O optimalnoj svjetovnoj i vjerskoj vlasti dalo bi se pak diskutirati. 
Primjenjivost Petrićeve vizije u suvremenom kontekstu možemo gledati kroz dvije komponente - utopije kao misaonog, budućnosnog i praktičnog koncepta, te konkretnih detalja i aspekata iz Petrićeva teksta. Utopijski duh treba usporediti s današnjim tendencijama i kritičkim promišljanjima suvremenih filozofa, sociologa, politologa, aktivista, društvenih kritičara te prosuditi postoji li on i u kolikoj mjeri. Drugu pak komponentu trebalo bi podijeliti na tri razine - onu ograničenu karakteristikama renesansnog razdoblja, onu koja je aktualna i danas te onu univerzalnu, nepromjenjivu i zauvijek danu.

\section{Odjek Petrićeva vremena u Sretnom gradu}

»Tako će jedni uživati u povlasticama, bezbrižnosti i udobnosti, a drugi raditi i truditi se, jednom riječju podnositi oskudicu « (Petrić, 1998, 29) - iako bi ova rečenica mogla biti izvučena iz nekog suvremenog hrvatskog publicističkog djela, ipak ju je napisao Petrić i to referirajući se na renesansni staleški sustav. Petrić, dakle, nije kritizirao feudalnu društvenu strukturu - prihvatio ju je kao samorazumljivu i na njoj gradio daljnje razine svoga sustava. To je i razumljivo ako znamo da je renesansa, koliko god predstavljala prekretnicu u odnosu na srednji vijek, još uvijek velikim dijelom počivala na feudalnom sustavu.

I Kukoč ističe Petrićeve makijavelistički grube formulacije koje odzvanjaju bešćutnim imoralističkim pragmatizmom ustanovljene staleške podjele (Kukoč, 1995, 177) kao renesansnu tekovinu, naglašavajući i mogući utjecaj odnosno poznavanje političkih spisa Niccola Machiavellija. Danas je demokracija pojam jednakosti, ljudskih sloboda i svojevrsna moderna utopija, dok su individualizacija, odvajanje od kolektiva, orijentacija ka samorealizaciji i samodovoljnosti tendencije suvremenog čovjeka. U tome odvajanju suvremeni čovjek želi biti po pravima i slobodama jednak svima ostalima te bi nametanje bilo kojeg drugog sustava osim demokracije, poglavito na psihološkom planu, izazvalo snažne otpore i nezadovoljstva. Privid slobode i jednakosti dovoljno je jak da se ljudi u njemu osjećaju ugodno i sigurno, makar tu slobodu i jednaka prava ne koristili.

Kada bi se pisala moderna utopija, ona bi svakako trebala biti modifikacija postojećeg sustava. Staleži spadaju u tabu teme i relikte prevaziđenih povijesnih sustava. Ipak, ne znači da se neki budući sustav neće vratiti na stalešku podjelu, kako su se neke samoorganizirane zajednice 
u Aziji i Latinskoj Americi vratile na socijalizam, što je iscrpno analizirala Marta Gregorčič (2013). Nadalje, nepriznavanje statusa građana trima nižim slojevima društva, propisivanje optimalnih godina za brak i slični modi vivendi spadaju također u svjetonazor svojstven razdoblju nekoliko stoljeća prije svekolike emancipacije. Ipak, svako književno, filozofsko, znanstveno ili umjetničko djelo vrijedan je i jedinstven spomenik povijesnog razdoblja u kojemu je nastalo, kao i koristan primjer razvoja ljudskoga uma, istraživanja i kreativnosti, koji može služiti kao uzorak ili obrazac mišljenja intelektualne elite toga vremena.

\section{Aktualnost Sretnog grada}

Osim biljega svoga vremena, Sretni grad je u određenim segmentima iznimno aktualan. Milivoj Solar jasno naznačuje suvremenost Petrićevih teorijskih nacrta:

"... on govori o izboru mjesta na kojem valja graditi grad, o najboljim uvjetima za trgovinu i o gotovo svim ključnim aspektima organizacije zajedničkog života, a da pri tome ne upada u kontradikcije s načelnim postavkama.« (Solar, 1998, 51)

Dodaje da je Petrićeva osnovna nakana posve suvremena zamisao obrazlaganja kako bi se mogao izgraditi najbolji mogući život za određenu ljudsku zajednicu unutar postojećih prirodnih i društvenih okolnosti.

»U središtu je Petrićeva zanimanja jedino neko moguće ostvarenje gradadržave uz takvu organizaciju života da barem obrazovani dio stanovništva u njemu može postići onaj najviši stupanj zadovoljstva i sreće koji se, u ovozemaljskom životu, uopće može ostvariti.« (Solar, 1998, 52)

Osim pragmatičkog razmišljanja, Petrić je i idealist što se očituje u tezi da u njegovom gradu neće biti gladi. S obzirom da diljem svijeta to još uvijek nije postignuto, štoviše, razlike između bogatih i siromašnih u mnogim zemljama postaju nepremostive, vidimo da ni do današnjeg dana nismo uspjeli naći rješenje za problem gladi. Diskurs optimalne količine proizvodnje i raspodjele i dalje je aktualan iako postoje određene socijalne mjere i inicijative (poput minimalnih primanja za najsiromašnije) koje su na tragu ublažavanja ovih razlika. Također, Petrić dodjeljuje svakom članu društva komad zemlje što znači da, ako bi svatko radio i zarađivao za sebe (makar i pod diktatom viših stale- 
ža), ne bi trebalo biti beskućnika niti nezaposlenih, što implicira barem elementarno zadovoljstvo, ako ne i sreću. Niti to danas nije postignuto, naročito otkad je kapitalizam preuzeo primat nad socijalizmom.

Ivona Mendeš $(1999,226)$ osvrnula se na Petrićevu aktualnost u smislu demografskog razmišljanja (problema prenapučenosti), kao i ekološke osviještenosti (onečišćenja, pošumljenosti prostora itd.). Kontrola rađanja danas je, naročito u napučenim i siromašnim zemljama, normalna i prihvaćena mjera, štoviše UNICEF i Svjetska zdravstvena organizacija financiraju i promiču taj tip planiranja obitelji. Budućnost možda nosi i potpunu kontrolu nad brojem stanovnika određenog grada ili zemlje, što moguće ne bi bilo blagotvorno za poimanje ljudske slobode. Ipak, stanovništvo Zemlje neprestano raste te će se državnici sigurno na ovo pitanje vratiti u skoroj budućnosti. Ekologija je pak danas moderna, mondena i popularna, a znanost sve više teži alternativnim obnovljivim izvorima energije, strogim kontrolama onečišćenja, rigidnim certificiranjem zdrave hrane itd.

\section{Univerzalne vrednote Petrićeve utopije}

Sva utopijska djela nužno uključuju i univerzalne vrednote. Iznimka nije niti Petrić, upravo iz razloga jer je učio od antičkih majstora filozofije.

»Duša je besmrtna i neraspadljiva, dovoljna samoj sebi, bez neke pripomoći izvana, i posjeduje sposobnost vlastitog održavanja. Drugi dio, tijelo, kao materijalna stvar, sastavljeno je iz nepostojanih dijelova, za vlastito održavanje samom sebi nedovoljno, već su mu za to potrebne izvanjske stvari. Prije svega o njemu mora brinuti i voditi ga duša.« (Petrić, 1998, 9)

Petrić ovdje ističe jednu istinu koju je istisnuo suvremeni materijalizam - da je čovjek dvojno biće i da navedene dihotomije uvijek treba biti svjestan. U psihologiji dušu imenujemo psihom ili sviješću. No osim podučavanja povijesti psihologije, povijesti filozofije, povijesti umjetnosti, djecu i mlade treba učiti ovim disciplinama u praksi - kako kontrolirati tijelo i emocije, kako filozofirati, kritički misliti, kako stvarati, pojmiti i prepoznati lijepo, dobro i pravedno. Petrić tvrdi da svaki čovjek teži svojem dobru, a duševno zadovoljstvo odnosno krepostan život smatra najvišim dobrom. To uključuje moralnost, umjerenost, suzdržljivost, slobodu i pravdu - univerzalne vrijednosti. Nijedan sustav niti vremensko razdoblje ovo neće promijeniti. Za razvoj vrlina 
pak nužno je zdravlje tijela i duha - uvijek važeći kriterij sreće. Sustavno formiranje ljudskog karaktera i stvaranje temelja za moralan, častan i sretan život potrebno je implementirati u društvo i socijalne procese, a odnos prema tome ukazuje na stanje u društvu. Kako u renesansi tako i danas, a tako će biti i sutra. Odgoj i obrazovanje temeljeni na etici, razvoju vrlina, očuvanju tijela i duha zdravim, usavršavanju prema talentima i predispozicijama nikada neće izgubiti na značaju te bi ih mogli nazvati vječnim $\mathrm{i}$ ispravnim smjernicama $\mathrm{k}$ utopiji.

Neoliberalni kapitalizam onemogućio je u velikoj mjeri bavljenje vrlinom jer je interes usmjerio na stjecanje materijalnog. Kada se pojedinac suočava s oskudicom osnovnih sredstava i dobara, bavljenje vrlinom dolazi kao sekundarna opcija, ako i ikakva. Kvalitetno obučavanje, prema Maslowljevoj hijerarhiji potreba, dolazi tek nakon materijalnog opstanka i sigurnosti. Sustav koji je temeljen na zgrtanju bogatstva nije dobar preduvjet za sretan grad, sretnu državu ili sretno društvo i ne otkriva usmjerenost na univerzalne vrijednosti. U tom smislu, Petrićeva vizija bila je ispred današnje stvarnosti. Nadalje, Ljerka Schiffler ističe kako je renesansni ideal čovjeka, na koji se referira i Petrić, odnosno stvaratelj novog (Schiffler, 1997, 44), arhetipska baza i suvremenog čovjeka, kao i nekog budućeg (post-suvremenog) ljudskog bića. Renesansni čovjek, homo universalis, onaj koji spada u viši stalež Petrićeva Sretnog grada - izumitelj, znanstvenik, prenositelj zakona i spoznaja, učitelj, majstor - ono je čemu treba težiti cijelo društvo i što su ideali koje vrijeme ne može nagristi. Konačno, božansko vrelo koje Petrić spominje na samom početku Sretnog grada također će uvijek biti prisutno dokle god je čovječanstva - ono skriveno, transcendentno, nedodirljivo, što uzrokuje sve zakone prirode i univerzuma, koje će i dalje čovjeka fascinirati, inspirirati, hraniti njegovu glad za znanjem, nutarnjim mirom i spoznajom. Te nebeske vode i danas su nam većinom nedostižne.

\section{Zaključak}

Utopijska promišljanja, zaključno, možemo podijeliti na dva oblika - utopiju u užem smislu i eutopiju ili pragmatičnu utopiju. U tom smislu, Sretni grad Frane Petrića uklopio bi se u ovaj drugi koncept. Njegova pragmatična eutopija sadrži sve tri komponente koje čine utopijsko djelo, a velik dio njegovih ideja primjenjive su i primjenjuju se 
danas. Povijesni slijed utopijskih djela podučava nas da idealno društvo još nije postignuto. Petrić je ponudio jedan model u kontekstu svoga vremena, koristeći filozofijske uzore iz antike, prilagođavajući svoj konstrukt renesansi, a smjerajući na univerzalnost i vječnu primjenjivost. Dijelom je u tome uspio i zato njegov priručnik vladajućima možemo smatrati vrijednim djelom hrvatske i svjetske filozofske baštine.

Današnji kapitalistički materijalizam, obilježen suštinskim nejednakostima i bučno suprotstavljen raznim oblicima vjerskih, nacionalnih i ideoloških fanatizama, povoljno je tlo za nastanak novih utopija. Iako se smatramo naprednom civilizacijom, svjesni smo da još uvijek nismo pronašli zadovoljavajuće društveno uređenje i da ne postoji država, društvo, grad ili zajednica za koje možemo reći da je pravedna prema svima.

Utopije se transformiraju, segmentiraju, reagiraju na impulse društva. Od kolektivnog, sveobuhvatnog pristupa, utopije se danas fokusiraju na određene skupine ljudi koje svojim borbama, glasom i naporima ostvaruju pravdu za sebe. Internet je povezao cijeli svijet pa svjedočimo i globalnim pokretima otpora protiv svih oblika ugnjetavanja, kao i solidarnosti protiv brojnih tipova nepravdi. Radi toga je prihvatljiv zaključak Hrvoja Jurića (2005) da je utopijsko maštanje potrebno i filozofiji i društvu, štoviše da je danas nužno svakome kome je stalo do drugačijeg i boljeg svijeta. Povijest je puna priča i mitova o nadljudima i herojima, koji ulaze u tradicije i kulture, svakodnevicu i jezik. Isto se odnosi i na utopijske priče koje nikada ne gube na zanimljivosti i intrigantnosti.

Dakle, utopizam danas nije mrtav - ideali i arhetipovi ne mogu umrijeti jer nisu dio materijalne stvarnosti. Jednako tako, niti idealizam se ne može ugasiti bez obzira koliko bio nepopularan, »zastario« $\mathrm{i}$ »namijenjen dokonim intelektualcima«. Utopistima i idealistima budućnosti ne treba puno da se dignu na noge, a među njima možda već sada izrasta neki post-suvremeni neorenesansni čovjek slojevitosti Frane Petrića. Njegovo djelo Sretni grad samo je jedan od primjera kako se utopije odnosno eutopije mogu primijeniti danas te otvaraju perspektive daljnje, sveobuhvatnije vizije razvoja društva. Ono može biti poticaj stvaranja novog suvremenog utopijskog društva koje će opet dijelom biti obilježeno današnjim (pred)određenostima i ograničenostima, ali $\mathrm{s}$ iskustvom dosadašnjih povijesno relevantnih primjera. Također, nudi izazov osmišljavanja načina na koji se može preduhitriti utopiju u zastarijevanju, odnosno stvaranja održivog modela koji bi se mijenjao kako se mijenja vrijeme odnosno evoluirao i iznova ciklički oživljavao. 


\section{Literatura}

Belicza, Biserka (1999), »Frane Petrić i medicina u djelu La città felice«, u: Schiffler, Ljerka (ur.), Zbornik radova VI. međunarodnog filozofskog simpozija Dani Frane Petriša: Cres, 13.-17. srpnja 1997., Zagreb: Hrvatsko filozofsko društvo; Cres: Grad Cres.

Bottin, Francesco (1999), »Francesco Patrizi e l'aristotelismo padovano«, u: Schiffler, Ljerka (ur.), Zbornik radova VI. međunarodnog filozofskog simpozija Dani Frane Petriša: Cres, 13.-17. srpnja 1997., Zagreb: Hrvatsko filozofsko društvo; Cres: Grad Cres.

Bučan, Danijel (2009), Kako je filozofija govorila arapski, Zagreb: Demetra.

Ćurko, Bruno (2010), »Petrić o vrlini i sreći u 'humanističkom' razdoblju«, Filozofska istraživanja, Zagreb, 30(3), str. 395-412.

Gerschmann, Karl-Heinz (1979), »Frane Petrić, La Città Felice - Jedna utopija između Thomasa Morusa i Campanelle«, Prilozi za istraživanje hrvatske filozofske baštine, Zagreb, 5(9-10), str. 43-56.

Gregorčič, Marta (2013), »Proizvajajoči boji samoorganiziranih skupnosti - potencie«, u: Štabi, Snežana; Dobnikar, Žiga i Pestotnik, Dejan (ur.), (Ne)odvisni, (Ne)zavisni, Independent?, Maribor: KID, ACE Kibla; Čakovec:Autonomni centar ACT, str. 28-45. Dostupno na: http://actnow.hr/wp-content/uploads/2013/02/KNJIGA_NMCB_FINAL-small-size.pdf.

Jurić, Hrvoje (2005), »Utopija - anti-utopija - post-utopija - utopija. Ili: utopija, filozofija i društveni život«, Arhe, Novi Sad, god. 2(3), str. 217-225.

Kukoč, Mislav (1995), »Petrićeva socijalnofilozofijska misao između realizma i utopizma«, Filozofska istraživanja, Zagreb, 15(1-2), str. 169-180.

Kukoč, Mislav (2009), »O najboljem ustroju mediteranskog polisa«, Filozofska istraživanja, Zagreb, 29(4), str. 641-656.

Kumar, Krishan (2001), »Utopija i antiutopija u dvadesetom stoljeću«, preveo Ivan Landripet, Diskrepancija, 2(4), str. 75-94. Dostupno na: https://www. yumpu.com/hr/document/view/20810019/utopija-i-antiutopija-u-dvadesetom-stoljecu.

Lazarević Di Giacomo, Persida (2010), »Dvostruko sretan grad Frane Petrića«, Filozofska istraživanja, Zagreb, 30(3), str. 385-394.

Majnarić, Niko i Gorski, Oton (1960), Grčko-hrvatskosrpski rječnik, Zagreb: Školska knjiga.

Mendeš, Ivona (1999), »Frane Petrić: Izabrani politički spisi«, prikaz, Politička misao, 36(3), str. 226-227.

Mumford, Lewis (2008), Povijest utopija, Zagreb: Jesenski i Turk. 
Petrić, Frane (1998), Sretan grad, Biblioteka Parnas, Zagreb: Matica hrvatska.

Schiffler, Ljerka (1997), »Grad čovjeka kao mjesto povijesti ili budućnosti utopije«, Frane Petrić - Od škole mišljenja do slobode mišljenja, Zagreb: Institut za filozofiju.

Solar, Milivoj (1998), »Pogovor«, u: Petrić, Frane, Sretan grad, Biblioteka Parnas, Zagreb: Matica hrvatska, str. 43-53.

\title{
THE HAPPY TOWN - THE APPLICABILITY OF PETRIĆ'S CONCEPT OF EUTOPIA IN THE MODERN CONTEXT
}

\begin{abstract}
Ana Jerković
Frane Petrić's The Happy Town (Sretni grad) is unquestionably one of many historic attempts at conceptualising a perfect place for the life and well-being of humans. This Renaissance philosopher, following Aristotle, outlined the location, social structure, educational model, and other elements of a polis that he believed would solve the shortcomings of the cities and states of his time. To what extent does his picture of the ideal city fit into today's modern context? Which ideas could and should function, and which are marked by the spirit and limitations of his time? Consequently, what universal values still have the same worth and necessity as they did hundreds of years ago?
\end{abstract}

Key words: Franciscus Patricius (Frane Petrić), The Happy Town, utopia, ideal state, modernity, universality 